\title{
Interventions to Increase Adherence to a Gluten Free Diet in Patients with Coeliac Disease: A Scoping Review
}

\author{
Humayun Muhammad $^{1, *}$, Sue Reeves ${ }^{1}$, Sauid Ishaq ${ }^{2}$ and Yvonne Jeanes ${ }^{1}$ \\ 1 Department of Life Sciences, University of Roehampton, London SW15 5PU, UK; \\ S.Reeves@roehampton.ac.uk (S.R.); Y.Jeanes@roehampton.ac.uk (Y.J.) \\ 2 Dudley Group of Hospitals, NHS Foundation Trust, Birmingham DY12HQ, UK; sauid.ishaq@nhs.net \\ * Correspondence: humayun.muhammad@roehampton.ac.uk
}

Received: 28 August 2020; Accepted: 18 September 2020; Published: 21 September 2020

check for updates

\begin{abstract}
Coeliac disease is a chronic inflammatory disorder of the small bowel, characterised by permanent intolerance to gluten. The only current and effective treatment for coeliac disease is a gluten free diet [GFD], however this is challenging for patients to adhere to. The review aims to identify published interventions designed to improve patients' adherence to a GFD. Ten intervention studies were identified and included within the review; whilst heterogeneous in delivery, all included an educational, behavioural, and practical element. Five interventions significantly improved dietary adherence, these included follow-up appointments, a telephone clinic, an online course, cooking sessions and psychological support. All studies were small and used varied methods to assess adherence. There is a paucity of well-designed interventions to promote dietary adherence, in future more robust methods for ascertaining adherence is needed, we recommend greater inclusion of dietetic assessment and combining more than one method for assessing adherence.
\end{abstract}

Keywords: coeliac disease; Intervention; gluten free diet

\section{Introduction}

Coeliac disease (CD) is a common, multi-system, immune mediated, chronic inflammatory disorder of the small bowel, affecting approximately $1 \%$ of the global population [1]. It is characterised by permanent intolerance to gluten in genetically predisposed people of any age or ethnic group [2]. Gluten is a protein composite found in wheat, barley, rye, and related plant species [3]. Furthermore, histologically, CD is characterised by villous atrophy of the small bowel mucosa [4], which may lead to malabsorption of micronutrients [5,6] and when symptomatic, it leads to diarrhoea, weight loss, and abdominal pain [7] in its classical form. In the majority of cases the condition responds to a gluten-free diet (GFD) [8], only to relapse after reintroduction of gluten into the diet $[9,10]$. Given that $\mathrm{CD}$ is a multisystem disorder [11], doctors and dietitians need to remain vigilant about the long-term complications of $C D$, which could include osteoporosis [12], anaemia, [13] and possibly intestinal lymphoma $[14,15]$

A GFD is the only treatment currently available $[16,17]$ but adherence to a GFD is challenging $[18,19]$, impacts quality of life and is considered a considerable treatment burden by the patient [20]. Adherence rates range from $42 \%$ to $91 \%$ [21] depending on the study method used [19]. Furthermore, it is not just a matter of modifying the diet alone, but rather involves the patient changing their entire lifestyle [22] and requires significant amounts of effort in terms of patient education, motivation, and behaviour change [23]. Many patients report that there are numerous social and practical issues that arise when trying to follow a GFD [24]. For this reason regular follow ups with healthcare professionals, such as a 
specialist dietitian, are advised to monitor adherence, provide appropriate support, and take necessary actions in the case of dietary transgressions [25], as this may improve and maintain adherence to a GFD [26]. Histology from a duodenal biopsy is the gold standard when assessing GF dietary adherence, as villous atrophy due to ingested gluten is visible. However, due to the invasive, costly and time-consuming nature of the procedure a variety of other methods are used in clinical and research settings; serology, faecal or urine tests, dietitian's assessment, interviews, validated and non-validated questionnaires, and patient reported adherence [19]; the challenges faced in determining adherence and methods available are discussed in detail by Muhammad et al. [19]. Identifying different types of interventions and considering their acceptability and success rates can help physicians and dietitians work with patients with CD to inform their approach for patients to ensure they receive evidence-based care and support. Therefore, the aim of this review is to identify published interventions that aimed to support patients with adherence to the gluten free diet.

\section{Results}

A total of 125 articles were identified and after a detailed assessment, 10 papers met the search criteria, one conference presentation was also identified, and the final number of studies included in the study was 11 . Figure 1 and Table 1 summarises the search strategy and results.

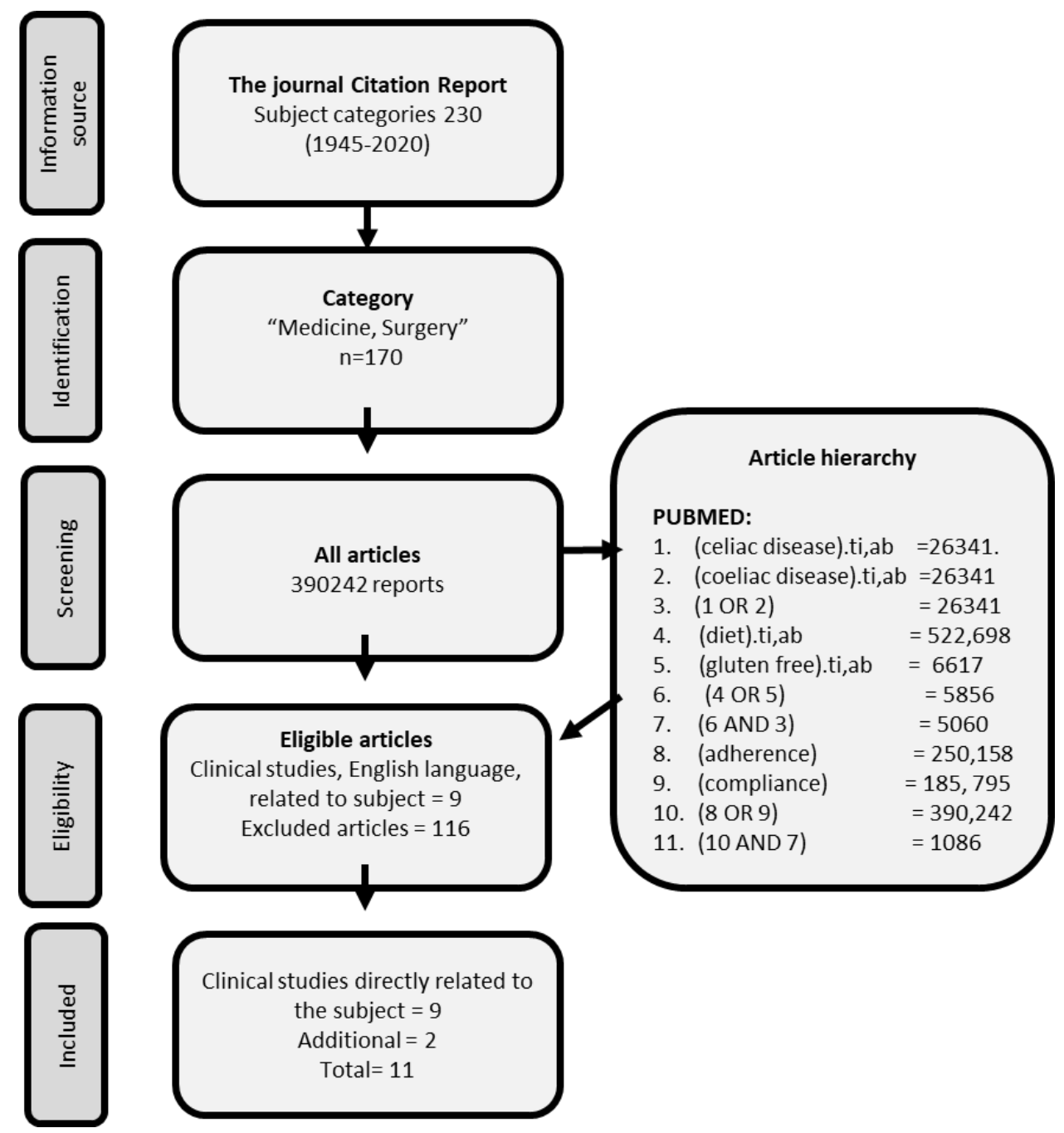

Figure 1. Flow chart illustrating the literature inclusion/exclusion strategy. 
Table 1. Interventions to promote gluten free dietary adherence in patients with coeliac disease.

\begin{tabular}{|c|c|c|c|}
\hline Study & $\mathbf{N}$ & Intervention & Key Findings \\
\hline $\begin{array}{l}\text { Addolorato et al., } 2004 \\
\text { Italy. [27]. }\end{array}$ & $\begin{array}{l}I=33 \\
C=33\end{array}$ & $\begin{array}{l}\text { Psychological support. FU 2-6 weeks. Self-reported, } \\
\text { clinical symptoms, serology, and histological recovery. }\end{array}$ & $\begin{array}{l}\text { Significant improvement in adherence in } \\
\text { intervention group as compared to } \\
\text { non-intervention. }\end{array}$ \\
\hline $\begin{array}{l}\text { Meyer et al., } 2004 \\
\text { Germany [28]. }\end{array}$ & $\begin{array}{l}I=32 \\
C=32\end{array}$ & $\begin{array}{l}\text { Computer-based interactive training program vs. } \\
\text { conventional training. FU } 3 \text { weeks. Knowledge } \\
\text { questionnaire. Indirect inference towards adherence. }\end{array}$ & $\begin{array}{c}\text { Both intervention and control groups } \\
\text { increased knowledge about CD. However, the } \\
\text { intervention group performed } \\
\text { significantly better. }\end{array}$ \\
\hline $\begin{array}{l}\text { Ring Jacobsson et al., } 2012 \\
\text { Sweden. [10] }\end{array}$ & $\begin{array}{l}I=54 \\
C=52\end{array}$ & $\begin{array}{l}10 \text { session educational programme. FU } 6 \text { months. } \\
\text { Psychological wellbeing test and gastrointestinal } \\
\text { symptoms. Indirect inference towards adherence. }\end{array}$ & $\begin{array}{l}\text { Significant improvement in psychological } \\
\text { well-being and gastrointestinal symptoms, } \\
\text { sustained at } 6 \text { months. }\end{array}$ \\
\hline $\begin{array}{l}\text { Sainsbury et al., 2013, } 2015 \\
\text { Australia }[29,30]\end{array}$ & $\begin{array}{l}I=46 \\
C=64\end{array}$ & $\begin{array}{l}\text { Online intervention "Bread and Butter." Immediate post } \\
\text { intervention and } 3 \text { month FU. Adherence: Validated } \\
\text { CDAT questionnaire. }\end{array}$ & $\begin{array}{l}\text { Significant improvement in adherence score, } \\
\text { in intervention group only. }\end{array}$ \\
\hline $\begin{array}{l}\text { Rajpoot et al., } 2015 \\
\text { India [26] }\end{array}$ & $\mathrm{I}=146$ & $\begin{array}{l}\text { Clinical follow up appointments; FU } 6 \text { months, no } \\
\text { control group. Adherence: non-validated dietary } \\
\text { history and food-labelled quiz questionnaire. }\end{array}$ & $\begin{array}{c}\text { Significant improvement in adherence at } \\
\text { over time. }\end{array}$ \\
\hline $\begin{array}{l}\text { Haas et al., } 2017 \\
\text { USA [31] }\end{array}$ & $\begin{array}{l}I=31 \\
C=30\end{array}$ & $\begin{array}{l}\text { Text Message intervention for children and adolescents. } \\
\text { FU } 12 \text { months. Validated CDAT questionnaire. }\end{array}$ & $\begin{array}{l}\text { No significant difference in change in } \\
\text { adherence scores over time between } \\
\text { intervention and control groups. }\end{array}$ \\
\hline $\begin{array}{c}\text { Wolf et al., } 2019 \\
\text { USA. Pilot study [32] }\end{array}$ & $\begin{array}{l}\mathrm{I}=12 \\
\text { No } C\end{array}$ & $\begin{array}{l}\text { Two cooking based nutrition education sessions. FU } 1 \\
\text { month. Adherence: Validated CDAT questionnaire. }\end{array}$ & $\begin{array}{l}\text { Significant improvements in adherence score } \\
\text { over time. }\end{array}$ \\
\hline $\begin{array}{l}\text { Wolf et al., } 2019 \\
\text { USA. Pilot study [32] }\end{array}$ & $\begin{array}{l}I=30 \\
\text { No C }\end{array}$ & $\begin{array}{l}\text { Gluten sensing device given to } 15 \text { adults and } 15 \\
\text { teenagers with coeliac disease. FU } 3 \text { months. } \\
\text { Adherence: Validated CDAT questionnaire. }\end{array}$ & $\begin{array}{l}\text { No significant difference between baseline and } \\
\text { follow-up adherence scores. }\end{array}$ \\
\hline $\begin{array}{c}\text { Dowd et al., } 2020 \\
\text { Canada, Pilot study [33] }\end{array}$ & $\begin{array}{l}I=14 \\
C=42\end{array}$ & $\begin{array}{l}\text { Participants with CD or gluten intolerance were given } \\
\text { access to an app for } 1 \text { month, educational, and practical } \\
\text { content. Adherence: Validated CDAT questionnaire. }\end{array}$ & $\begin{array}{l}\text { No significant difference between baseline and } \\
\text { follow-up adherence scores. }\end{array}$ \\
\hline $\begin{array}{l}\text { Jeanes et al., } 2020 \text { and Muhammad et al. } \\
\text { UK. [34,35] }\end{array}$ & $\begin{array}{l}I=30 \\
C=57\end{array}$ & $\begin{array}{l}\text { Personalised Telephone Clinic. FU } 6 \text { months. } \\
\text { Adherence: Validated CDAT questionnaire. }\end{array}$ & $\begin{array}{l}\text { Significant improvement in knowledge and } \\
\text { adherence score in intervention group only. }\end{array}$ \\
\hline
\end{tabular}

Abbreviations - CD: Coeliac Disease, CDAT: Coeliac Dietary Adherence Test [36], GFD: Gluten Free Diet, FU: Follow up period, QoL: Quality of Life. 


\section{Discussion}

The studies cited above (Table 1) have all considered the issue of increasing adherence to a GFD with different approaches; however, it could be argued that some may lack general applicability and or clinical relevance for day-to-day practice. It is however accepted that the issue of low adherence to a GFD is widely recognised [21] and the need for successful interventions for patients is clear. The theory of planned behaviour (TPB) [37] is arguably one of the leading models for the prediction of human social behaviour and is certainly highly cited [38]. TPB considers that intentions to perform different behaviours can be accurately predicted from attitudes toward the said behaviour, perceived behavioural control, and subjective norms. Sainsbury et al. [29] and Muhammad et al. [34] utilised the principals of the TPB within their interventions. Sainsbury et al. [29] reported TPB could help explain the mechanism of action responsible for some changes in intention and behaviour after the intervention, but habit strength and actual behavioural control also played a role in GFD adherence [29].

\subsection{Follow Up Appointments to Increase Adherence to a GFD}

International guidelines recommend patients engage in regular follow up with a healthcare professional [23]; however, success in terms of adherence to the GFD can vary. Rajpoot et al. [26] considered the role of follow up in a prospective study of 146 patients who were both treatment naïve $[n=54]$ and already following a GFD $(n=92)$. Patients were requested to complete the coeliac symptoms index and dietary history. Following them up prospectively they reported a significant increase [from 53.3\% to $92.4 \%$ ] in adherence to a GFD, unfortunately, there was no control group. This is promising compared to an observational study [39] that reported there were no significant differences in symptoms and dietary adherence between regularly followed-up patients $(6.3 \%),(n=94)$ and patients with no follow up $15.1 \%(n=527, p=0.343)$. However, with so many factors influencing GF dietary adherence [19] it is difficult to establish cause and effect for follow up and adherence from this study. Randomised controlled studies to explore healthcare professional follow-up and adherence are not feasible as it is not ethical to have a no intervention group. However, in parts of the UK, there are areas where patients are not offered regular reviews who could act as a control group [40]. The evidence base for healthcare interventions are limited and it is an area that warrants further robust study.

\subsection{Telephone Clinic Intervention to Improve Dietary Adherence}

Telephone clinics can have the advantages that they do not require patients to travel to the hospital, use public transport, nor pay car-parking fees, which have been highlighted as important to patients with coeliac disease [41]. Telephone clinics have been shown to work successfully with different groups of patients [42,43] and were proven to be useful at the time of the COVID-19 pandemic $[44,45]$. A telephone clinic could therefore be suitable for follow up appointments with patients with coeliac disease, and are used by some dietitians and nurses [40]. Jeanes et al. [35] and Muhammad et al., [34] reported on the benefits of a personalised telephone clinic in a study with a six month follow up; the telephone clinic was led by a healthcare professional with expertise in coeliac disease, the intervention group consisted of adults with coeliac disease not adhering to a GFD [ $n=30]$, and a control group who were adhering to a GFD $(n=57)$. In the intervention group there was a $0 \%$ attrition rate. Results reported significant improvements in GF knowledge $(p<0.01)$, and GF dietary adherence score $(p<0.001)$ in the intervention group. This study provides an evidence base that follow-up via remote access to patients can be effective and sustained for up to six months.

In The Netherlands, online consultations were compared with face-to-face appointments for children and young adults with CD $(n=156)$, whilst they were unable to assess the effect on dietary adherence, they reported that online appointments improved CD related QoL [46]. A robust study comparing face-to-face consultations and remote access is needed to inform healthcare professionals to design services for patients with CD. Pritchard et al. [47] reported that adults who were offered a 
telephone clinic were more likely to receive an annual review, have their symptoms assessed and their diet reviewed compared with those who had general practitioner follow up provision. Patients are diverse in their needs and preferences; thus, a telephone clinic is not suitable for all, but should be considered as part of the service available to patients with CD.

\subsection{Computer Based Education Interventions to Increase Adherence to a GFD}

Two studies have assessed the role of computer based educational programmes as interventions to increase adherence to a GFD, and both interventions improved CD knowledge. Meyer and colleagues [28] utilised a computer-based interactive training program (CBITP) combined with interactive exercises as an intervention to assess its effect on adherence to a GFD $(n=64)$. The primary outcome of this study was improvement in knowledge about $C D$ rather than adherence but the indirect effect of this knowledge was assumed to be a surrogate for increased adherence, an association between the two has since been published [48]. Participants were randomly allocated to the CBITP, whilst the control group were provided with written instructions. Both the intervention and control groups increased their knowledge about CD; although, the intervention group exhibited a significantly better outcome. Interestingly the authors reported that knowledge appeared to have no relationship with the behaviour of patients after learning more about CD and adherence to a GFD, further information about the long-term clinical implications is warranted.

An online intervention by Sainsbury et al., [30] was a goal-directed, randomised controlled trial (RCT) with the primary outcome being to improve GF dietary adherence as measured using the coeliac dietary adherence test (CDAT) [36]. The patients selected all had biopsy-confirmed CD and were randomly allocated into intervention $(n=101)$ and control groups $(n=88)$. There was a high attrition rate, with only $50 \%$ of participants completing the online programme. After three months, the intervention group had increased their knowledge about CD and improved GF dietary adherence scores from baseline $(p<0.001)$, while the wait-list group's scores remained unchanged $(p=0.67)$. These two computer based interventions both showed successful outcomes, however it should be noted in both studies patients were all members of a Coeliac Disease Society (CDS) which may introduced selection bias, as patients from such societies have previously been reported to have better adherence to a GFD [21]. Furthermore, computer literacy and financial accessibility to online resources need to be considered. Both studies provided a theoretical as well as practical baseline for future computer based interventions, and provided an additional resource for patients with $\mathrm{CD}$.

\subsection{Mobile Phone Based Interventions to Increase Adherence to a GFD}

Given that many patients now have a mobile phone, Haas and colleagues [31] evaluated the role of text messages in relation to increasing GF dietary adherence in children and young adults $(n=64)$. The intervention group $(n=31)$ were sent 45 unique text messages over a three-month study period, while the control group received standard of care treatment. Adherence was measured with serum anti-tTG (IgA) and de-amidated gliadin peptide (IgA) levels. However, no significant differences were noted in GF dietary adherence between groups, nor over time. It should be noted that the age of patients in the study ranged from 12 to 24 years, an age group that has previously been reported as having generally low adherence rates [49,50]. Recently, Dowd et al. [33] assessed the effectiveness of a smart phone app in a pilot study and reported improvement in symptomatic profile but inconsistent results for adherence to a GFD. This is an evolving area and more research is needed.

\subsection{Improving Psychological Wellbeing to Increase Adherence to a GFD}

Two earlier studies concentrated on improving the psychological wellbeing of patients living with CD and the impact on adherence to a GFD. In the first study, one group of patients was given psychological support $(n=33)$, whereas the other served as a control group and received standard care $(n=33)$ [27]. The intervention group were significantly less depressed at six months and a significantly smaller proportion were not adhering to the GFD compared with the control group ( $9 \%$ 
versus $39 \%$; $p=0.02$ ). A recent meta-analysis of eight cross-sectional studies $(n=1644)$, reported a moderate association between poorer GFD adherence and greater depressive symptoms $(r=0.398$, $95 \% \mathrm{CI}=0.321-0.469)$, though the authors did highlight need for more robust longitudinal studies to provide clarity in the cause and effect [51]. A randomised control trial involved a dedicated 10 -session "Coeliac School" intervention $[n=54]$, and those who received information in relation to $C D$ at home $(n=52)$. The aim of the study was to assess the effects of an active method of patient education on the psychological well-being of women with coeliac disease in remission [52]. The intervention group had significantly improved psychological well-being and gastrointestinal symptoms at 10 weeks and remained sustained at 6 months follow up. Unfortunately, adherence to a GFD was not directly measured.

\subsection{Cooking-Based Intervention to Increase Adherence to a GFD}

Cooking-based interventions have been shown to improve attitudes, self-efficacy, and a healthier dietary intake in both adults and children [53]. Given that the change to a GF diet can be a challenge for many patients with coeliac disease, culinary classes to help this transition and encourage healthy eating have obvious benefits. Wolf et al. [54] evaluated a small cooking-based intervention that promoted gluten free adherence and aimed to improve quality of life. Twelve adults were recruited and took part in two sessions of $4.5 \mathrm{~h}$ with a dietitian and a chef. At one month follow up, the authors reported improvements in adherence to GFD, CDAT scores $(p=0.011)$, quality of life $(p<0.000)$, depression $(p=0.004)$, and anxiety state scores $(p=0.002)$. A larger cohort of patients with a longer follow-up is needed to fully evaluate the benefits of this intervention.

\subsection{Is There a Role for Gluten Detecting Devices to Increase Adherence to a GFD}

At present there is not enough evidence to promote gluten detecting devices to improve dietary adherence and they may even increase anxiety in teenagers [32].

\section{Material and Methods}

\section{Literature and Search Strategy}

A scoping literature search was conducted in June 2019 and updated in April and September 2020 using PUBMED. The publication-year-restrictions were articles published since 2000. The following terms were applied, searching for titles and abstract (TiAb): (celiac OR coeliac disease). TiAb, AND gluten free diet AND adherence OR compliance. Additionally, reference lists of all selected articles were also scanned to increase the yield of eligible papers. Furthermore, eligible papers were selected based on original English language clinical studies of human participants. Books and case reports, reviews, and articles not relevant to the topic were excluded. The search strategy was conducted separately by two authors (HM, SR). The review did not require ethical approval.

\section{Conclusions}

Whilst it is widely recognised that adhering to a GFD is challenging there is a paucity of robust intervention studies to improve patient gluten free dietary adherence, this is surprising as it is the only treatment option available for coeliac disease. The predominance of studies used the CDAT questionnaire or serology, in future greater inclusion of dietetic assessment and combining more than one method for assessing adherence is recommended to improve the accuracy of determining adherence [55]. Studies tended not to indicate the ethnicity of participants, representation of non-Caucasian participants has previously been reported [19]. Further research in this area is clearly needed and should aim to recruit patients from hospital data bases diagnosed on histological grounds to minimise selection bias and would go towards ensuring an ethnically representative sample is recruited. The authors suggest future studies collect data on quality of life alongside adherence, to assess a more holistic impact of the intervention on a patient. 
Author Contributions: Conceptualisation, H.M., S.R., Y.J. and S.I.; methodology, H.M., S.R. and Y.J.; formal analysis, H.M., S.R., Y.J. and S.I.; writing—original draft preparation, H.M., S.R. and Y.J.; and writing-review and editing, H.M., S.R., Y.J. and S.I.; All authors have read and agreed to the published version of the manuscript.

Funding: This research received no external funding.

Conflicts of Interest: The authors declare no conflict of interest. H.M. and Y.J. have previously received Schär Institute International Nutrition Award.

\section{References}

1. Singh, P.; Arora, A.; Strand, T.A.; Leffler, D.A.; Catassi, C.; Green, P.H.; Kelly, C.P.; Ahuja, V.; Makharia, G.K. Global prevalence of celiac disease: Systematic review and meta-analysis. Clin. Gastroenterol. Hepatol. 2018, 16, 823-836.e2. [CrossRef] [PubMed]

2. Shan, L.; Molberg, O.; Parrot, I.; Hausch, F.; Filiz, F.; Gray, G.M.; Sollid, L.M.; Khosla, C. Structural Basis for Gluten Intolerance in Celiac Sprue. Science 2002, 297, 2275-2279. [CrossRef] [PubMed]

3. Farrell, R.J.; Kelly, C.P. Celiac sprue. N. Engl. J. Med. 2002, 346, 180-188. [CrossRef] [PubMed]

4. Marsh, M.N.; Crowe, P.T. 5 Morphology of the mucosal lesion in gluten sensitivity. Baillière's Clin. Gastroenterol. 1995, 9, 273-293. [CrossRef]

5. Di Sabatino, A.; Corazza, G.R. Coeliac disease. The Lancet 2009, 373, 1480-1493. [CrossRef]

6. Reilly, N.R.; Fasano, A.; Green, P.H. Presentation of celiac disease. Gastrointest. Endosc. Clin. N. Am. 2012, 22, 613-621. [CrossRef]

7. Rampertab, S.D.; Pooran, N.; Brar, P.; Singh, P.; Green, P.H. Trends in the presentation of celiac disease. Am. J. Med. 2006, 119, 355.e9-355.e14. [CrossRef]

8. Rubio-Tapia, A.; Rahim, M.W.; See, J.A.; Lahr, B.D.; Wu, T.-T.; Murray, J.A. Mucosal Recovery and Mortality in Adults With Celiac Disease After Treatment With a Gluten-Free Diet. Am. J. Gastroenterol. 2010, 105, 1412-1420. [CrossRef]

9. Silvester, J.A.; Rashid, M. Long-term follow-up of individuals with celiac disease: An evaluation of current practice guidelines. Can. J. Gastroenterol. 2007, 21, 557-564. [CrossRef]

10. Ring Jacobsson, L.; Friedrichsen, M.; Göransson, A.; Hallert, C. Does a Coeliac School increase psychological well-being in women suffering from coeliac disease, living on a gluten-free diet? J. Clin. Nurs. 2012, 21, 766-775. [CrossRef]

11. Kochhar, G.S.; Singh, T.; Gill, A.; Kirby, D.F. Celiac disease: Managing a multisystem disorder. Clevel. Clin. J. Med. 2016, 83, 217-227. [CrossRef] [PubMed]

12. Meyer, D.; Stavropolous, S.; Diamond, B.; Shane, E.; Green, P.H. Osteoporosis in a North American adult population with celiac disease. Am. J. Gastroenterol. 2001, 96, 112-119. [CrossRef]

13. Mahadev, S.; Laszkowska, M.; Sundström, J.; Björkholm, M.; Lebwohl, B.; Green, P.H.; Ludvigsson, J.F. Prevalence of celiac disease in patients with iron deficiency anemia-A systematic review with meta-analysis. Gastroenterology 2018, 155, 374-382.e1. [CrossRef] [PubMed]

14. Silano, M.; Volta, U.; De Vincenzi, A.; Dessì, M.; De Vincenzi, M. Collaborating centers of the Italian registry of the complications of coeliac disease effect of a gluten-free diet on the risk of enteropathy-associated T-cell lymphoma in celiac disease. Dig. Dis. Sci. 2008, 53, 972-976. [CrossRef] [PubMed]

15. García-Hoz, C.; Crespo, L.; Lopez, N.; De Andrés, A.; León, R.R.; Santón, A.; Garriga, M.; Butz, E.; León, F.; Roy, G. The intracellular intensity of CD3 on aberrant intraepithelial lymphocytes is a prognostic factor of the progression to overt lymphoma in Refractory Celiac Disease Type II (RCD-II/Pre-Enteropathy-Associated T cell Lymphoma). Dig. Dis. 2020. [CrossRef]

16. Herman, M.L.; Rubio-Tapia, A.; Lahr, B.D.; Larson, J.J.; Van Dyke, C.T.; Murray, J.A. Patients with celiac disease are not followed up adequately. Clin. Gastroenterol. Hepatol. 2012, 10, 893-899.e1. [CrossRef]

17. McAllister, B.P.; Williams, E.; Clarke, K.A. Comprehensive review of celiac disease/gluten-sensitive enteropathies. Clin. Rev. Allergy Immunol. 2018, 57, 226-243. [CrossRef]

18. Zarkadas, M.; Dubois, S.; MacIsaac, K.; Cantin, I.; Rashid, M.; Roberts, K.C.; La Vieille, S.; Godefroy, S.; Pulido, O.M. Living with coeliac disease and a gluten-free diet: A Canadian perspective. J. Hum. Nutr. Diet. 2012, 26, 10-23. [CrossRef]

19. Muhammad, H.; Reeves, S.; Jeanes, Y.M. Identifying and improving adherence to the gluten-free diet in people with coeliac disease. Proc. Nutr. Soc. 2019, 78, 418-425. [CrossRef] 
20. Shah, S.; Akbari, M.; Vanga, R.; Kelly, C.P.; Hansen, J.; Theethira, T.; Tariq, S.; Dennis, M.; Leffler, D.A. Patient perception of treatment burden is high in celiac disease compared with other common conditions. Am. J. Gastroenterol. 2014, 109, 1304-1311. [CrossRef]

21. Hall, N.J.; Rubin, G.; Charnock, A. Systematic review: Adherence to a gluten-free diet in adult patients with coeliac disease. Aliment. Pharmacol. Ther. 2009, 30, 315-330. [CrossRef] [PubMed]

22. Olsson, C.; Hrnell, A.; Ivarsson, A.; Sydner, Y.M.; Hörnell, A. The everyday life of adolescent coeliacs: Issues of importance for compliance with the gluten-free diet. J. Hum. Nutr. Diet. 2008, 21, 359-367. [CrossRef]

23. Al-Toma, A.; Volta, U.; Auricchio, R.; Castillejo, G.; Sanders, D.S.; Cellier, C.; Mulder, C.J.; E A Lundin, K. European society for the study of coeliac disease (ESsCD) guideline for coeliac disease and other gluten-related disorders. United Eur. Gastroenterol. J. 2019, 7, 583-613. [CrossRef]

24. Abu-Janb, N.; Jaana, M. Facilitators and barriers to adherence to gluten-free diet among adults with celiac disease: A systematic review. J. Hum. Nutr. Diet. 2020. [CrossRef] [PubMed]

25. Pietzak, M.M. Follow-up of patients with celiac disease: Achieving compliance with treatment. Gastroenterology 2005, 128, S135-S141. [CrossRef] [PubMed]

26. Rajpoot, P.; Sharma, A.; Harikrishnan, S.; Baruah, B.J.; Ahuja, V.; Makharia, G.K. Adherence to gluten-free diet and barriers to adherence in patients with celiac disease. Indian J. Gastroenterol. 2015, 34, 380-386. [CrossRef] [PubMed]

27. Addolorato, G.; De Lorenzi, G.; Abenavoli, L.; Leggio, L.; Capristo, E.; Gasbarrini, G. Psychological support counselling improves gluten-free diet compliance in coeliac patients with affective disorders. Aliment. Pharmacol. Ther. 2004, 20,777-782. [CrossRef]

28. Meyer, K.G.; Fasshauer, M.; Nebel, I.-T.; Paschke, R. Comparative analysis of conventional training and a computer-based interactive training program for celiac disease patients. Patient Educ. Couns. 2004, 54, 353-360. [CrossRef]

29. Sainsbury, K.; Mullan, B.; Sharpe, L. Predicting intention and behaviour following participation in a theory-based intervention to improve gluten free diet adherence in coeliac disease. Psychol. Heal. 2015, 30, 1063-1074. [CrossRef]

30. Sainsbury, K.; Mullan, B.; Sharpe, L. A randomized controlled trial of an online intervention to improve gluten-free diet adherence in celiac disease. Am. J. Gastroenterol. 2013, 108, 811-817. [CrossRef]

31. Haas, K.; Martin, A.; Park, K. Text message intervention (TEACH) improves quality of life and patient activation in celiac disease: A randomized clinical trial. J. Pediatr. 2017, 185, 62-67.e2. [CrossRef] [PubMed]

32. Wolf, R.L.; Green, P.H.; Lee, A.R.; Reilly, N.R.; Zybert, P.; Lebwohl, B. Benefits from and barriers to portable detection of gluten, based on a randomized pilot trial of patients with celiac disease. Clin. Gastroenterol. Hepatol. 2019, 17, 2605-2607. [CrossRef] [PubMed]

33. Dowd, A.J.; Warbeck, C.B.; Tang, K.T.; Fung, T.; Culos-Reed, S.N. MyHealthyGut: Findings from a pilot randomized controlled trial on adherence to a gluten-free diet and quality of life among adults with celiac disease or gluten intolerance. Digit. Heal. 2020, 6. [CrossRef]

34. Muhammad, H.; Revees, S.; Ishaq, S.; Jeanes, Y. Telephone clinic improves gluten free dietary adherence in adults with coeliac disease; sustained at 6 months. Frontline Gastroenterol. 2020, in press.

35. Jeanes, Y.; Muhammad, H.; Ishaq, S.; Mayberry, J.; Reeves, S. Intervention improves knowledge of gluten-free foods and dietary adherence in adults with coeliac disease. Proc. Nutr. Soc. 2020, 79. [CrossRef]

36. Leffler, D.A.; Dennis, M.; George, J.B.E.; Jamma, S.; Magge, S.; Cook, E.F.; Schuppan, D.; Kelly, C.P. A simple validated gluten-free diet adherence survey for adults with celiac disease. Clin. Gastroenterol. Hepatol. 2009, 7, 530-536.e2. [CrossRef]

37. Ajzen, I. Theory of planned behavior. Handb. Theor. Soc. Psychol. 2011, 1, 438.

38. Tornikoski, E.; Maalaoui, A. Critical reflections-The Theory of Planned Behaviour: An interview with Icek Ajzen with implications for entrepreneurship research. Int. Small Bus. J. Res. Entrep. 2019, 37, 536-550. [CrossRef]

39. Pekki, H.; Kurppa, K.; Mäki, M.; Huhtala, H.; Laurila, K.; Ilus, T.; Kaukinen, K. Performing routine follow-up biopsy 1 year after diagnosis does not affect long-term outcomes in coeliac disease. Aliment. Pharmacol. Ther. 2017, 45, 1459-1468. [CrossRef]

40. Kallos, S.; Jeanes, Y. Cross-sectional survey of the dietetic provision for adults with coeliac disease in the UK. J. Hum. Nutr. Diet. 2020, 33, 6-15. 
41. Muhammad, H.; Reeves, S.; Jeanes, Y. Qualitative Interviews to Explore Patient Preference for Health Care Led Interventions to Promote Gluten Free Dietary Adherence; Coeliac: London, UK, 2019; p. 54.

42. Mole, G.; Murali, M.; Carter, S.; Gore, D.; Broadhurst, J.; Moore, T.; Vickers, P.; Miles, A. A service evaluation of specialist nurse telephone follow-up of bowel cancer patients after surgery. Br. J. Nurs. 2019, 28, 1234-1238. [CrossRef] [PubMed]

43. Casey, R.; Powell, L.; Braithwaite, M.; Booth, C.; Sizer, B.; Corr, J. Nurse-led phone call follow-up clinics are effective for patients with prostate cancer. J. Patient Exp. 2017, 4, 114-120. [CrossRef] [PubMed]

44. Luciani, L.G.; Mattevi, D.; Cai, T.; Giusti, G.; Proietti, S.; Malossini, G. Teleurology in the time of covid-19 pandemic: Here to stay? Urology 2020, 140, 4-6. [CrossRef] [PubMed]

45. Smith, A.C.; Thomas, E.E.; Snoswell, C.L.; Haydon, H.M.; Mehrotra, A.; Clemensen, J.; Caffery, L.J. Telehealth for global emergencies: Implications for coronavirus disease 2019 (COVID-19). J. Telemed. Telecare 2020, 26, 309-313. [CrossRef] [PubMed]

46. Vriezinga, S.; Borghorst, A.; Marle, E.V.D.A.-V.; Benninga, M.; George, E.; Hendriks, D.; Hopman, E.; De Meij, T.; Jong, A.V.D.M.-D.; Putter, H.; et al. E-Healthcare for Celiac Disease-A Multicenter Randomized Controlled Trial. J. Pediatr. 2018, 195, 154-160.e7. [CrossRef]

47. Pritchard, L.; Waters, C.; A Murray, I.; Bebb, J.; Lewis, S. Comparing alternative follow-up strategies for patients with stable coeliac disease. Front. Gastroenterol. 2019, 11, 93-97. [CrossRef]

48. Halmos, E.P.; Deng, M.; Knowles, S.R.; Sainsbury, K.; Mullan, B.; Tye-Din, J.A. Food knowledge and psychological state predict adherence to a gluten-free diet in a survey of 5310 Australians and New Zealanders with coeliac disease. Aliment. Pharmacol. Ther. 2018, 48, 78-86. [CrossRef]

49. Schilling, K.W.; Yohannessen, K.; Araya, M. Perception of following gluten-free diet and adherence to treatment in pediatric patients with celiac disease. Rev. Chil. Pediatr. 2018, 89, 216-223. [CrossRef]

50. White, L.E.; Bannerman, E.; Gillett, P.M. Coeliac disease and the gluten-free diet: A review of the burdens; factors associated with adherence and impact on health-related quality of life, with specific focus on adolescence. J. Hum. Nutr. Diet. 2016, 29, 593-606. [CrossRef]

51. Sainsbury, K.; Marques, M.M. The relationship between gluten free diet adherence and depressive symptoms in adults with coeliac disease: A systematic review with meta-analysis. Appetite 2018, 120, 578-588. [CrossRef]

52. Jacobsson, L.R.; Friedrichsen, M.; Göransson, A.; Hallert, C. Impact of an active patient education program on gastrointestinal symptoms in women with celiac disease following a gluten-free diet. Gastroenterol. Nurs. 2012, 35, 200-206. [CrossRef]

53. Hasan, B.; Thompson, W.G.; Almasri, J.; Wang, Z.; Lakis, S.; Prokop, L.J.; Hensrud, D.D.; Frie, K.S.; Wirtz, M.J.; Murad, A.L.; et al. The effect of culinary interventions (cooking classes) on dietary intake and behavioral change: A systematic review and evidence map. BMC Nutr. 2019, 5, 29. [CrossRef] [PubMed]

54. Wolf, R.L.; Morawetz, M.; Lee, A.R.; Koch, P.; Contento, I.R.; Zybert, P.; Green, P.H.; Lebwohl, B. A cooking-based intervention promotes gluten-free diet adherence and quality of life for adults with celiac disease. Clin. Gastroenterol. Hepatol. 2019. [CrossRef] [PubMed]

55. Lau, M.S.; Mooney, P.D.; A Rees, M.; White, W.L.; Marks, L.J.; Hadjivassiliou, M.; Sanders, D.S. OWE-022 Gluten free diet adherence assessment using CDAT and BIAGI questionnaires in patients with coeliac disease. Small Bowel Nutr. 2018, 67, A160-A161.

(C) 2020 by the authors. Licensee MDPI, Basel, Switzerland. This article is an open access article distributed under the terms and conditions of the Creative Commons Attribution (CC BY) license (http://creativecommons.org/licenses/by/4.0/). 